\title{
Early Childhood Education and the Reforming of Universal Program: Radicalism Movement in Indonesia
}

\author{
Juniar Laraswanda Umagapi \\ Graduate Master Degree students of Political Analysis and Public Policy \\ National Research University Higher School of Economics \\ Moscow, Russia \\ laraswanda17@gmail.com
}

\begin{abstract}
In this paper, the author examines the educational preparation and the impact of early childhood education programme by the government and how the result of it. The study aimed to identify successes and barriers of the early childhood education program in Indonesia and to analyse the current policy implementation to the obstacle of early childhood education. The author also wants to make a comparison for the implementation of the universal program by UNESCO in some countries and look at the need for that programs to apply in Indonesia especially regarding radicalism issue. This paper will discuss findings the relation of radicalism action by youth with the early childhood education system in Indonesia. Thematic analysis revealed the importance of communication with parents, relationships with previous service providers, opportunities for professional learning and organisational support. The author also wants to discuss the result of Early Childhood Care and Education Programme (ECCE) by UNESCO with the Indonesian government in the rural areas. Lastly, in the conclusion, the author wants to analyse the impact of school teaching to extremism action by youth or the chance of youth to join any radicalism group that leads to the extremism action.
\end{abstract}

Keywords-childhood education programme, UNESCO, radicalism, extremism, rural areas

\section{INTRODUCTION}

School is the best place to learn everything; children try to learn new things start from the family and after that school. After their parents, they will look for the teacher, and that is why a teacher plays an important role to build up the image of the child. Children in their age become a secure object for other people that try to lead their thinking the way the adult wants. School is the best place to learn everything; children try to learn new things start from the family and after that school. After their parents, they will look for the teacher, and that is why a teacher plays an important role to build up the image of the child. Children in their age become an easy object for other people that try to manipulate their mind and follow their ideology even it is from the radical community. Subject or literature aspect may influence the radicalism thinker to act radically the way it is.
Education from an early age is vital to teach people from a child how to act in the real world so they will survive with their action. Most countries believe that to educate people and to create a good skilful new generation we must start from their early ages that's why the government from mostly all the country apply their early childhood education system to create their decent generation and to prepare them to compete in the more global area. The government must put a lot of effort into their citizens and education will make our generation becomes a wonderful person in the future. We must prepare them with scientific skill and moral lesson, and it always starts from their house and school.

The government must pay attention to their education system, they must control the literature given by the teacher, so they will not teach the student bad things. We believe that if we want to change the nation let's start from our kids and use education as a tool to teach them. Form a superior generation in the middle. Global competition can be done by organizing education that provides the most extensive opportunity for children students to grow and develop according to their potential, talents, interests and its ability.

Schools and colleges also play an important role in forming a shared identity, strengthening democratic consolidation and as a space that forms public civilization. Ironically, schools and colleges lose their essence in this process. Teachers/lecturers who are believed to be "facilitators of civilization," instead tend to be intolerant and radical. Their exclusive diversity attitude closes their way too tolerant attitudes.

\section{METHOD}

This research will use the qualitative method and case study method to collect all the data. The reason for using the qualitative approach is to make sure the main problem would be ascertained. The case study method is taken from the internet website, book, journal, newspaper and any other source that will help to get the contentious discussion regarding this issue and then conclude the research. 


\section{RESULT AND DISCUSSION}

\section{A. The Important of Early Childhood Education System}

The early childhood education system is important to teach the youth from their early age — not only academics but the primary lesson to survive in this world. That's why the government need to paid attention for this matter and support this system financial or either supervision aspect. We can see from the table below how the early childhood coordination mechanism in Indonesia.

\section{TABLE I. EARLY CHILDHOOD COORDINATION MECHANISM} IN INDONESIA

\begin{tabular}{|c|c|c|c|}
\hline Name & Location & Membership & Function \\
\hline $\begin{array}{l}\text { Early } \\
\text { Childhood } \\
\text { Education } \\
\text { Consortium }\end{array}$ & $\begin{array}{l}\text { Directorate- } \\
\text { General of Out- } \\
\text { of-School } \\
\text { Education and } \\
\text { Youth, Ministry } \\
\text { of Education }\end{array}$ & $\begin{array}{l}\text { Mid-level } \\
\text { technical } \\
\text { government } \\
\text { officials from } \\
\text { concerned } \\
\text { ministries and } \\
\text { coordinating } \\
\text { bodies, early } \\
\text { childhood experts, } \\
\text { NGO } \\
\text { representatives }\end{array}$ & $\begin{array}{l}\text { To develop, } \\
\text { evaluate } \\
\text { coordinate and } \\
\text { advocate non- } \\
\text { formal early } \\
\text { childhood } \\
\text { programmes for } \\
\text { 0-8-year olds }\end{array}$ \\
\hline $\begin{array}{l}\text { Early } \\
\text { Childhood } \\
\text { Education } \\
\text { Forum }\end{array}$ & $\begin{array}{l}\text { Directorate- } \\
\text { General of Out- } \\
\text { of-School } \\
\text { Education and } \\
\text { Youth, Ministry } \\
\text { of Education }\end{array}$ & $\begin{array}{ll}\text { High-level } & \\
\text { government } & \\
\text { officials } & \text { from } \\
\text { concerned } & \\
\text { ministries } & \text { and } \\
\text { bodies } & \end{array}$ & $\begin{array}{l}\text { Improving } \\
\text { curriculum and } \\
\text { management; } \\
\text { conducting } \\
\text { capacity- } \\
\text { building } \\
\text { exercises to } \\
\text { develop and } \\
\text { coordinate early } \\
\text { childhood } \\
\text { policies }\end{array}$ \\
\hline
\end{tabular}

We can see from the second table also, how the government action for give the financial support in this issue. ECD expenditure may not be adequate to provide quality services for all. According to Law No. 20/2003 on the National Education System, a minimum of 20 percent of government spending must be on education. But funding for other sectors, as well as preschool education, may not be sufficient, and financing for preschools is limited.

TABLE II. EARLY CHILDHOOD DEVELOPMENT BUDGET ACROSS SECTORS IN INDONESIA, 2013 [2]

\begin{tabular}{|l|l|l|l|}
\hline \multicolumn{1}{|c|}{ Sector } & \multicolumn{1}{c|}{ Budget (IDR) } & \multicolumn{1}{c|}{ Budget (USD) } & \multicolumn{1}{c|}{$\begin{array}{c}\text { Percentage of } \\
\text { GDP }\end{array}$} \\
\hline Education & $1,569,218,277,000$ & $162,414,000$ & 0.0187 \\
\hline Health & $2,743,515,353,000$ & $283,954,000$ & 0.0327 \\
\hline Nutrition & $281,488,770,000$ & $29,134,100$ & 0.0034 \\
\hline $\begin{array}{l}\text { Child } \\
\text { protection }\end{array}$ & $22,206,908,000$ & $2,298,410$ & 0.0003 \\
\hline $\begin{array}{l}\text { Social } \\
\text { protection }\end{array}$ & $656,087,490,000 \mathrm{a}$ & $67,905,000$ & 0.0078 \\
\hline
\end{tabular}

Note: Currency exchange rate for January 1, 2013, has been used for the conversion of the budget amounts into USD. GDP is for 2013. GDP = gross domestic product; IDR = Indonesian rupiah; USD = US dollar. a. This figure includes budget from the National Family Planning Coordinating Board (BKKBN) allocated for parenting programs.

Government spending on education still low compare to another aspect such as health, nutrition, child protection, and social protection even though we agree that education will be the primary tool to change our environment to become a better place. We can change the quality of the human resource through education so that they can compete in a broader arena such as the international area. The government must take it seriously this matter because to support this program the government must give a support in financial or supervision matter.

\section{B. What is the impact to Radical action by Youth?}

If we see the news, every day we can see the story about brawl among the students, based on psychology perspective young people tend to do everything in a group and they are in the age to get influenced by people so easily, and they will believe others easily. That's why the people from a bad organization or bad environment tend to recruit their members to start from their child age or teenager because in that age young still cannot make difference between bad and good that's why it is so easy to influence them.

Radicalism will lead to the terrorism and terrorism issue becomes an important and hot topic right now, Indonesia suffers from this issue also. Like what happened in May this year, a terror happened, and suicide bombing makes Indonesia becomes the headline of international media for a long time. From the past until now, Indonesia still becomes a country that becomes a victim of a terrorist attack and the government still try hard to handle this issue in the best way.

Radical Islam spread quickly in most countries and no other than Indonesia, Indonesia is the highest Islamic population in the world. The rise of radical Islam is not a new phenomenon in the Southeast Asian country. Spread peacefully by Sufi preachers coming from India and Persia (and thus generally moderate and pluralistic), since the early 1980s Indonesia's Islam has been under Saudi Arabia's conservative influence. The Middle Eastern country began to fund the creation of religious schools and circulate booklets and pamphlets promoting Wahhabism. The most immediate consequence of this was that radical versions of Islam, new in the archipelagic country, started competing with more tolerant versions of the same religion. It is not a coincidence that the Council of Indonesian Ulama (Majelis Ulama Indonesia, MUI), which defines the parameters of religious orthodoxy, took more conservative stances, maintaining that Indonesia, from a secular state, had to be transformed into an Islamic state. Also, more recently, this organ has fomented intolerant and violent behaviour against the religious Other, issuing fatwas forbidding marriages between Muslims and non-Muslims, encouraging the enforcement of sharia or depicting pluralism and liberalism as incompatible with the Islamic civilisation [3].

Children are so easy to follow other people because they are the easy target to manipulate. Right now, the issue of terrorism becomes the most sensitive issue. The significant terrorist movement already makes a big movement to recruit their new member in all the country across the globe. Children 
like to do everything in a group, so it is important for the parent to know what kind of groups they are involved. In their teenage time, they are mostly become rebellious because of their age. Therefore, parents cannot force them with action to do whatever we want. This attitude will influence their bad feeling to us. They will become more rebellious if we use domestic violence to them.

Mass media is an effective tool for the image of politics and create a public opinion in west mass media, especially mass media in the United States become becomes a way of important propagandas when US government target Indonesia in the campaign anti-global terrorism. This is what happened after the 9/11 tragedy, Indonesia also becomes a target of United States that they said Indonesia also a place for Radical Islam. Indonesia also a country that protects the terrorist and becomes a country that most terrorist hide. Trial by the press is one of the top cases in media mass in+ media world. Because of the political ideology interest, media is sometimes taking an action in the character assassinations. The principle of presumption of innocence becomes not important anymore for this interest.

The image that left by the media international is the limitation an extremist by the Islamic in Indonesia. The impact is Muslim in Indonesia sometimes have the radical image by the public of United States. Nevertheless, according to the critiques of Indonesia in the University of Ohio, Prof William Liddle, most of the Muslim in Indonesia is not radical it is so far away from the real image. In the conference: Islam in Indonesia: Berkuasa Massal "that happen in New York on 7 January 2002, Liddle said that extremism is only the language of media that shows the image of Indonesia becomes radical. Liddle said that the sad accusation of the international about Islam in Indonesia it is happening because of the extreme publication of international media including mass media in the United States [4].

\section{Solution}

We can start from the basic problem start from school; we know that youth learn everything from school so of course, they will do everything that their teacher asked them to do. The quality of the teacher and the literature teaches in the school becomes important. The curriculum system is also important.

The Islamic literature that affiliate with the movement and Islamic organisation that develop in several cities in Indonesia. Solo became the city that gave birth to the most publishers that actively produced Islamicist literature, followed by Yogyakarta, Jakarta, and Bogor. The purpose of the Islamicist literature is to teach students about the basic principle of the religion that we must do not attack each other, and we also must respect other people. But radicalism movement is so easy to spread, and many people become a victim for the propagandist to influence their mindset that to protect our religion and faith it is okay to use violence, or we call it radical action.

We can see the graphic below shows the vital role of religious education for countering the violent extremism in Indonesia.

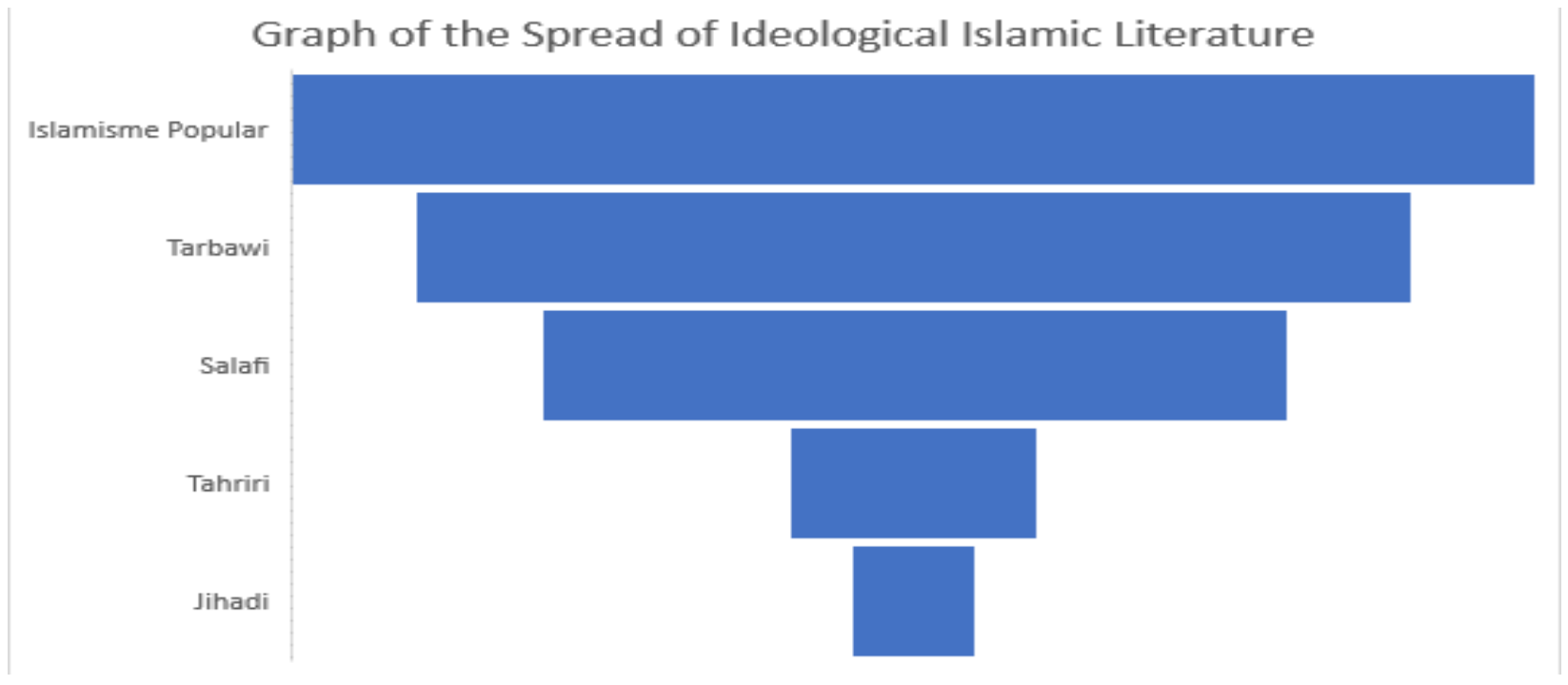

Fig. 1. Spread of Islam Literature [5]

How youth get influenced by the literature in school, especially when the teacher does not pay attention to what their students read will make them do not know how to control the radicalism mindset that will come later. International policy mostly focused on countering terrorism. The result is not maximal because only the reactive for what happened because of the terrorism. The National Counterterrorism Agency said there were 2.7 million Indonesians involved in a series of terror attacks. Even that number does not include followers and sympathizers of terrorist networks. "That number is about 1 percent of the total population of Indonesia," said expert researcher from BNPT, Sidratahta Mukhtar, Wednesday, January 19, 2016 [6].

Whereas there are thousands of others, who carry out terrorism movements, both recruitment, training and the formation of terrorist communities, the security approach is 
considered to fail to understand and contain terrorism more comprehensively. Terrorism is not only a matter of security and strategic studies but is also related to economic, psychological and even scientific problems.

Young people have a strong tendency to limit the influence of radicalism and terrorism. Patient understanding of violence and terror enters through social media and online media. The availability of articles, Friday sermons, and media materials on the domination of fundamental understanding of jihadist make young, especially students in school and university become more radical in religious understanding.

The phenomenon of religious radicalism is rooted in cultural poverty, that is, what enters cultural territory is seen as a religious doctrine, whereas the rules are different. Politics is a cultural area; therefore, Islam does not require whether the country is in the form of a kingdom or a Republic, all of which are left to the benefit of local culture.

Radicalism arises due to various causes, both related to conflicts of interest, dissatisfaction with state actors, as well as those relating to coercion of ideas or ideologies of the states and government. Ref [7] stated that before the modern period generally, the causes of Islamic radicalism were internal, namely the response to various internal problems of Muslims such as the drastic shrinking of Muslim political entities and conflicts between them. Many Muslims believe that this appalling situation arises due to the destruction of the social morality of the Muslims themselves, which is the impact of belief and false religious practices and ignoring the pure Islamic teachings.

The level of intolerance and radicalism of Indonesian youth, especially students in school or even in the university has become a separate agenda to be completed. It can also be said to have reached an alarming level. A national survey on diversity in schools and universities in Indonesia in 2017 found $23.35 \%$ of students stated: "the act of terrorism through suicide bombings was recognized in Islam," and $37.71 \%$ admitted, "jihad is a value in Islam that is directed to non-Muslim" [8]. Showing that percentage we can conclude that young people are in danger and it will give a bad impact on the society if that kind of mindset still dominated the thinking of the youth. Young people always like to socialize with many people; they are getting easily influence in one environment.

Radical understanding began to enter and develop into formal education institutions. Fundamental understanding has developed into formal education institutions. Activities such as the Student Council, religious activities (ROHIS) and other extra-curricular activities cannot be separated from the threat of the spread of radicalism. This condition is increasingly worrying considering that school institutions have limitations to oversee all school activities.

The source of information and references in studying Islam is one that shapes the perspective of students. There are three primary sources of students in studying the Islamic religion, namely courses in Islam, the Internet and religion-based student organizations [8]. People must work together to stop all kind of activities that they think it is dangerous and lead to radical movement. It is so difficult for the government to control what happened in the school, so it must come from society.

\section{CONCLUSION}

Early child education system will be the best program to teach the youth how to act well in the social environment. They will learn the good things in school so that they can apply in their everyday life. School is the place that most youths spend their time and the area that youth meet their friends and socialize with others. If we see the news, the extremism action in school, universities will lead for the criminal act. Radical movement even though it is only brawling or fighting with each other it is shown that the youth will not be afraid to harm the other people, and it will lead to the more radical behaviour such as Terrorism.

Terrorism also will harm many people because it is called the radical religion action that most people believe to protect their faith or own believes they must hurt other people. That's mostly many people make a wrong interpretation of this principle. In school, children and teacher are the most important actors; they must not force children to do whatever they want. As Nelson Mandela quote "Education is the best weapon to change the world" its show that education is the critical aspect that can change everybody life. People who live in a developing country still face a lot of problem regarding the system of education like Indonesia. The problem such as the access of education, the number of teachers who have not been evenly distributed, as well as the quality of teachers themselves are insufficient and lack of access to education in Indonesia especially in rural area [9].

\section{REFERENCES}

[1] A. Denboba, A. Hasan, and Q. Wodon, "Early Childhood Education and Development in Indonesia: An Assessment of Policies Using SABER," World Bank Studies. Washington, DC: World Bank, 2015.

[2] Budget documents of Education \& Health Ministries, "The accountability reports of Social Affairs Ministry; and Women Empowerment and Child Protection Ministry," Executive Summary "Enhancing the Role of Religious Education in Countering Violent Extremism in Indonesia," Convey Indonesia, 2013

[3] E. Valdameri, "Radical Islam Is Gaining Ground in Indonesia," 2007. [Online]. Available: https://thewire.in/external-affairs/radical-islamindonesia.

[4] I. Idia and R. Asep, “Amerika, Terorisme dan Islamophibia” Fakta dan Imajinasi jaringan Kaum Radikal, 2007.

[5] Policy Brief Series."Mengimbangi Literature Islamis di Kalangan Indonesia," Enhancing The Role of Religious Education in Countering Violent Extremism in Indonesia by Convey Indonesia on Issue 14, vol. $1,2018$.

[6] I. Hamdi, "BNPT Sebut Ada 2,7 Juta Orang Terlibat Terorisme," 2006. [Online]. Available: https://nasional.tempo.co/read/737905/bnpt-sebutada-27-juta-orang-indonesia-terlibat-terorisme.

[7] A. Azra, "Radikalisme Islam Indonesia," Tempo, 15 Desember 2002

[8] PPIM UIN Jakarta, “Api dalam Sekam keberagaman gen Z," National Survey about diversity in school and universities in Indonesia, 2017.

[9] J. L. Umagapi, "Playing in Politics Towards the Better Education Policy in Indonesia," Journal the Politics of Journal Magister Political Science University of Hasanuddin, vol. 2, no. 2, 2016. 